\title{
I love liver: a romance
}

\section{A design for life.}

\section{Larissa Lai}

It has taken me almost four weeks of late nights and taxed my mochaccino machine to the limits. But Mira is ready. She began as a prototype for FreshCleanse's Liver Replacement line, but her capacity for toxin decomposition was weaker than that of the liver McDowell Hill came up with in the cubicle next to mine. (What's with people who have last names for first names? It's so tacky.) For whatever reason, the Boss Man liked Mackie's design better, and so Mira fell to the waste heap of Great Inventions That Die on the Drawing Board.

To be honest, I felt quite despondent about it. It wasn't just a blow to the ego, I'm used to those. It was more that ... well, there was something about Mira, a kind of beauty, extraordinary really. Something poignant about her lines, something tender and sad about her soft, brown-grey texture. The fact that she would never go into production threw me into a bit of a funk.

It took me a few days to realize that this wasn't something I would just get over, as I have with countless other designs. By the fourth day, even after two mochaccinos and a double dose of Beverly, my despondency seemed worse. I phoned in sick and went back to bed. My doctor had expressly told me how careful I had to be with Beverly. "This generation of antidepressants is more precise but also much more potent than what you're probably used to," she told me, "so you have to watch your dosage very carefully." Whatever. It was too late now anyway. I closed my eyes. Halfway between sleep and waking, I thought I saw Mira slip in beside me, larger than life, pillowy soft and a little slippery, in a smooth, sleek sort of way. I reached out to caress an elegant fluke. It was almost comforting.

A ringing phone woke me at four in the afternoon. It was McDowell Hill. "You better get down here right away," he said. "The boss doesn't care how sick you are. That weird liver you designed - it's jumped protocols and has infected the mainframe. We're losing thousands of hours of $R \& D$ with every minute that passes. You better get your pathetic, depressed butt down here ASAP." For a minute I thought: "Who cares, you smarmy creep. I hope Mira burns the whole operation down.' But then I'd be out of a job. I got my pathetic, depressed butt down to the office.

The place was in chaos. The Tech Support boys were mousing as fast as their caffeinepumped little hands could move, jibing and

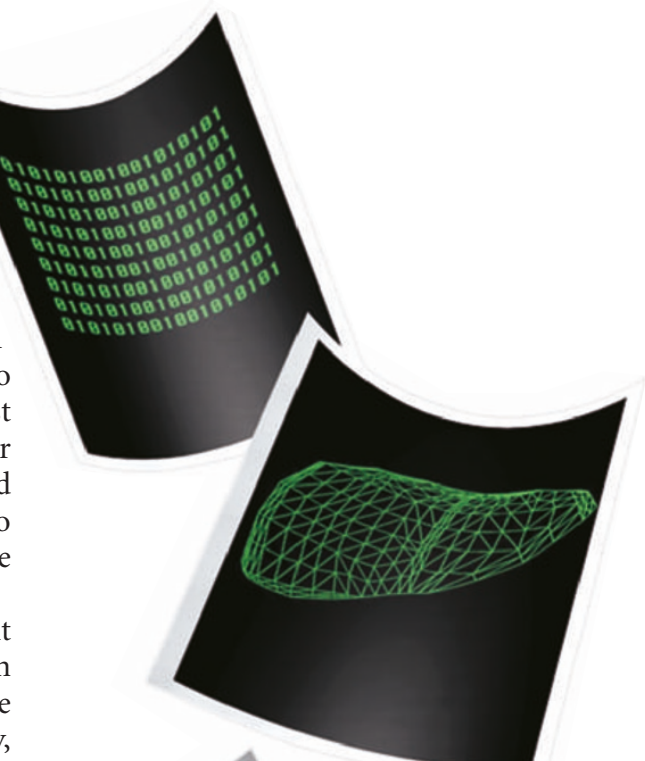

You know, I'm not sure she's entirely stable."

"Anna was born here," the Boss Man said.

"Damn right," I said, by way of letting them know I'd been there behind them listening. Mackie turned, and shot me the evil eye.

"Can you fix this, Anna?" asked the Boss Man.

I pushed Mackie out of the way and slid into my seat. "That's the thing about organics," I said. “They aren't static. They do things. They mutate."

"We need better firewalls," Mackie said.

I didn't fix anything. It was more like, I appealed to Mira. I coaxed her gently with a few smatterings of code. I showed her the initial lines of a heart I was working on. Mira returned to her original storage location. She spat back most of the information she'd devoured on her rampage. It wasn't all in the correct order, and some of it had been corrupted, but it was pretty much all there. It would keep Tech Support busy for a week or two. I went back home to my depression, wondering if Mira was depressed too.

When I got back to my apartment, my computer was on. Mira was floating back and forth across the screen like a pretty brown-grey fish in an aquarium. I don't know how she got from FreshCleanse to here, but I suppose such things are relatively easy these days. I opened her up and began the modifications. I made her a little larger. I cribbed some slug programming off a biologist's website to give her underside motility. To give her eyes seemed too strange somehow. Antennae looked better. I altered her coloration just slightly to give her an attractive iridescent sheen. It's taken me a few weeks, but now she is finally ready to print. What's wrong with the print function? Never mind, I'll just try it again. There we go. Hello, Mira! She tumbles gracefully from the printer and slithers across my office floor. Oops. Must have pressed 'print' twice. Hello, Mira Two! ... Oh no, something is wrong. Another flap of liver emerges from the printer. She's cute. I can manage three. Here comes another. Am I in some kind of trouble? another the whole time. I found McDowell and the Boss Man at my cubicle, rifling furiously through my password-protected files with brazen impunity. Who needs this job? I thought. "I don't understand how a liver design can go viral like that," the Boss Man was saying.

"Over-rationalization," said Mackie. "The protocols are too close. And that was one weird little liver Anna designed. That's what you get for hiring these foreigners. 